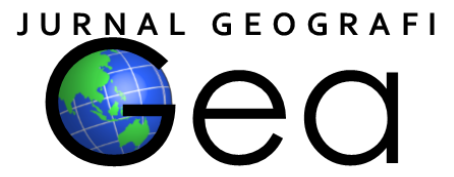

\title{
IMPACT OF COASTAL FLOOD ON BUILDING, INFRASTRUCTURE, AND COMMUNITY ADAPTATION IN BUKIT BESTARI TANJUNGPINANG
}

\author{
Muhammad Hanif $^{1^{*}}$, Beben Graha Putra ${ }^{1}$, Rizki Atthori Hidayat ${ }^{1}$, Ravidho Ramadhan ${ }^{2}$, \\ Ahyuni $^{1}$, Afriyadi ${ }^{3}$, Wan Shafrina Wan Moh Jaafar ${ }^{4}$, Dedi Hermon ${ }^{1}$, Ernieza Suhana \\ Mokhtar ${ }^{5}$ \\ ${ }^{1}$ Department of Geography, State University of Padang, Indonesia \\ ${ }^{2}$ Department of Physic, Andalas University, Indonesia \\ ${ }^{3}$ Department of Economic, STIE Pembangunan, Tanjungpinang. Indonesia \\ ${ }^{4}$ Department of Institute Perubahan Iklim, Universiti Kebangsaan Malaysia, Malaysia. \\ ${ }^{5}$ Department of Architecture, Universitas Fajar Makassar, Indonesia \\ ${ }^{6}$ Faculty of Architecture, Planning \& Surveying. Universiti Teknologi MARA, Malaysia. \\ *hanif12mphy@gmail.com
}

\begin{abstract}
Coastal flood in Indonesia, namely as banjir rob, is a phenomenon that increases seawater to inundate around the tidal area. In Tanjungpinang, cases of coastal floods become a serious problem for people living in this area. This research aims to model the coastal flood inundation by modeling water inundation with a maximum level increase scenario. Its model was used to estimate coastal floods' impact on houses, buildings, and infrastructures with scenario 2 meters of sea-level rise. On the other hand, the budget loss for restoration was estimated to study the effort of community adaptations with the ECLAC RAB method and observation to understand community adaptation. It was found that the spatial model succeeded in zoning inundation areas, which had a significant impact on houses, buildings, worship places, schools, and industrial at many 4112 units. From this case, the budget loss for the restoration of the physical environment was estimated at around 61994014.75 USD. In addition, the survey revealed the existing condition before and after the coastal flood. Several community efforts for adaptation were developing houses on stilt and hoarding the lowest land on-site location for building houses.
\end{abstract}

Keywords: coastal flooding, tidal flat, geospatial

\section{INTRODUCTION}

The glacial component has undergone rapid changes since the Pleistocene epoch. The most urgent factor in changing this glacial component is climate change on the earth's surface. Climate change has become reasoned by the increasing trend of global warming in the last few decades. This phenomenon has been marked by an increasing the earth's surface temperature (Al'ala, 2017). Changes in this glacial component impact sea level which is increasing over time (Zevenbrengn, 2011, Haigh, 2020). Increased sea levels will affect people's lives on the shoreline because this area is affected by tidal activities. One of the disasters caused by a sudden rise in sea level is tidal flooding (Nofrizal, 2019).

Tidal floods are different from ordinary floods, especially in the cause of the flood. The intensity of rainfalls is no reason by the coastal 
flood but occurs because the tide process is of maximum value. In addition, the high sea level condition of the land surface on the coast also affects the occurrence of floods and their impacts (Purnama, 2015, Kopp, et al, 2015, Lorie M, 2020). Planning the state of the land and residents around the coast plays an essential role in minimizing the impact of the tidal flood. Planning for land and population conditions can only be done with accurate predictions of future tidal floods in an area (Holli, 2012 and Ackere 2016). Tidal floods that occur in densely populated areas cause significant physical and material losses, mainly if they occur in urban areas. In addition to the potential to take lives, tidal flooding also can damage residences and infrastructure in the city (Haigh et al., 2020 and Tiggeloven, 2020). One of the urban areas that have the potential for tidal flooding is the city of Tanjung Pinang. Tanjungpinang is a city located in the southern part of Bintan Island, and this is the capital of the Riau Islands Province. Low land conditions and dense population in the coastal area of Tanjung Pinang make the area vulnerable to significant losses during tidal flooding (reference). Therefore, a detailed study is needed about the impact of tidal flooding in the city of Tanjung Pinang as consideration for urban planning on the coast affected by tidal flooding. This detailed study can be carried out using a history of tidal flooding on the shoreline of Tanjung Pinang City.

This study will model the impact of the tidal flood that occurred in the Bukit Bestari subdistrict. This location has a densely populated area in the tidal flats of the city of Tanjung Pinang. The modeling uses geospatial technology from data on land cover, coastline, river flow, topography, and community settlements. Hidayat (2020) The geospatial technology is very useful for identification, analysis, and estimate spatial data by many sources, criteria and information. The unique character from geospatial technology can combine spatial and non-spatial data then create a new thematic map. The strong power of geospatial technology made it different from other technology because this technology bases earth reference or coordinate system.
The output from the spatial model could represent a real geographical condition in the area. The available spatial data is really useful for policymakers (Rahaman. 2020)

This research focuses on modeling water inundation as coastal flood, and to estimate the number of houses, buildings, social facilities, and infrastructure damage basic coastal flood scenario, then calculate the total dollar a budget loss out for restoration area. To studies about community, adaptation has been implemented in flood areas, the limitation of the adaptation idea is especially the way of adaptation in building construction. The results of this model will interpret the impact on buildings and other infrastructure in the area and estimate it in dollars. The output of this research has expected to become the consideration basis for urban planning in minimizing the impact of a coastal flood.

\section{RESEARCH METHOD Material}

This research was conducted by analyzing secondary data and primary observation. The first data is administration, land cover, coastal line, rivers stream, this data has taken from Indonesia Geospatial Agency BIG on web site http:// tanahair.indonesia.go.id this data is free to access. Map of units building, the infrastructure it took from Regional Planning and Development Agency. The data Shuttle Radar Topography Mission SRTM has taken from USGS http//:earthexplorer.usgs.gov free access. The function of SRTM data for making slopes on the land surface. In the process of data preparation, we collect a standard data analysis map scale of 1:25.000.

\section{Methodology}

Several procedures followed the process of analyzing data. The first step is modeling inundate of the coastal flood. The second step is to calculate the impact of a coastal flood on many buildings, Infrastructure and estimate budget loss for restoration. The last stage is observation in the study area to understand the strategy of community adaptation in building construction to live around the coastal area which faced the coastal 
flood. The detailed procedure and process data analysis can be seen in Figure 1.

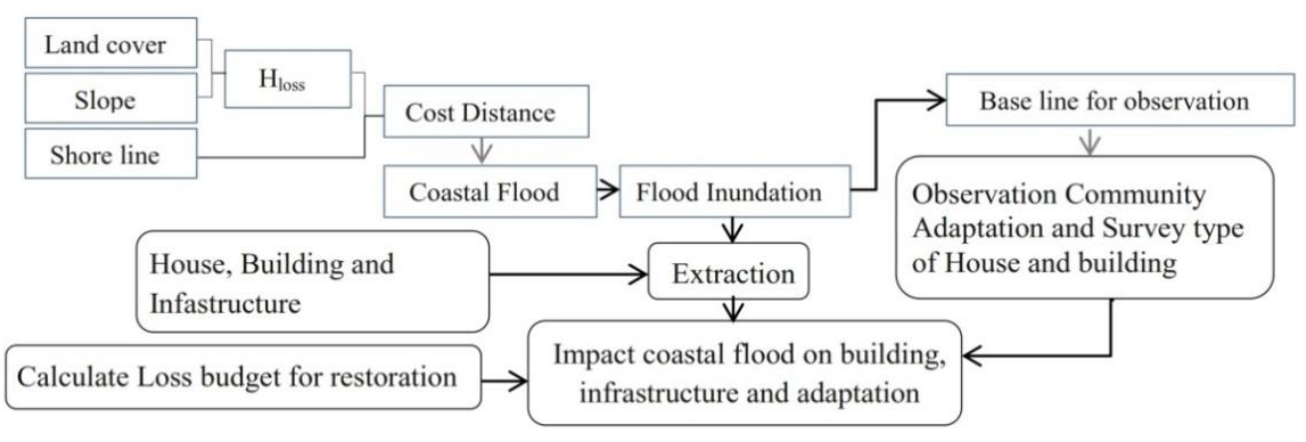

Figure 1. Research procedures

\section{Analysis Data}

\section{Modeling Inundate of Coastal Flood 1.1 Land surface roughness}

The land surface roughness was analyzed using coefficient (n) data. The (n) data is helpful as a basis for calculating the power of surface roughness which collaborates both indicators of the land surface to reduce the transmission of water and wave energy from the shoreline during high tides. The value of each coefficient is based on each object's ability to reduce and absorb water and waves energy. None affected such as water bodies are like in estuary it has a minimal value because the river mouths are very fast to transfer water and wave from the shoreline.

Table 1. Coefficient land surface roughness

\begin{tabular}{lll}
\hline Roughness & Land cover & Coefficient value \\
\hline R1 & Water body & 0.007 \\
R2 & Shrub & 0.04 \\
R3 & Forest & 0.07 \\
R4 & Plantation & 0.035 \\
R5 & Bare land & 0.015 \\
R6 & Agricultural area & 0.025 \\
R7 & Built-Up & 0.045 \\
R8 & Mangroves & 0.025 \\
R9 & Fish pond & 0.01 \\
\hline
\end{tabular}

$$
\mathbf{H}_{\text {loss }}=\left(\left(167 \mathrm{n}^{2} / \mathrm{H}_{0}{ }^{1 / 3}\right)+5 \sin \mathrm{S}\right)
$$

Where Hloss is a reduction of water level and energy in the interval of shoreline, $\mathrm{n}$ is coefficient of land surface roughness, $\mathrm{H} 0$ is a maximum scenario of high water level of the tidal wave, and $\mathrm{S}$ is the slope of the land surface. The last step to modeling inundates flood coastal is calculating cost distance to present the effect of maximum flood high from the shoreline to the environment. Irawan (2016) explains that the maximum water level of tidal is around 2,77 meters as $\mathrm{H} 0$ in Batam Island. The data on the maximum height value of Batam Island is used as an approach to the highest possible tide in Tanjungpinang
Source. Beryman (2006).

because these two islands have the same geographical characteristics.

\subsection{Coastal Flooding}

The coastal flooding model was built by cost distance analysis. In this process, as a source of cost distance source (cd s) is shoreline which is the conduct of seawater energy and inundation, and the cost raster sources ( $\mathrm{cr} \mathrm{s}$ ) is the value of raster sources. Cost raster ( $\mathrm{cr} \mathrm{a}$ ) is the result of land surface roughness or Hloss. Indarto (2013) explained that the basic principle of calculating the cost distance is to calculate the cost of each cell that 
is passed. The fundamental equation of cost distance behind ArcGIS software is:

$$
\text { Cost Distance }=c d s+\frac{c r s+c r a}{2}
$$

Where: $\mathrm{Cds}=$ is cost distance sources, $\mathrm{crs}=$ cost raster sources, cost raster a.

\section{Coastal Flood $=c d-$ Max cd}

The result of cost distance analysis contains the spatial information of coastal flood inundation. It has a value from 0 to high value, which depends on the case and processing analysis. This data must be extracted using the number of high-level water increases (introductory scenario) which 2 meters were chosen in this scenario. It means that the extraction elevation data must be provided in the interval from 0 to 2 meters extracted from SRTM images. Finally, the height of 2 meters will obtain lookup is done, and the original coastal flood data must be cut using the altitude data in high from 0 to 2 meters. Thus, the flood inundation zone was focused on the area with a high number of 2 meters.

\section{Impact Coastal Flood to Building and Infrastructure \\ 2.1 Overlay data}

The map overlay technique was used to calculate the impact of flood inundation on houses, buildings, social facilities, and infrastructure. This technique obtained the infrastructure network that was affected by flood inundation. In addition, the number of houses and buildings can be calculated by the map overlay technique.

\subsection{ECLAC Method}

The Economic Commission for Latin America and the Caribbean (ECLAC). This method uses the overall and macroeconomic impact of the disaster. This method only covers the conceptual and methodological aspects of measuring or estimating the damage due to disasters on capital and loss of production flows of goods and services subjectively, including the temporary impact on macroeconomic variables (Sesunan (2014).

The line with the ECLAC methodology can lead the environmental damage due to disasters, which is viewed from assets and services using data on the budget plan/ Rencana Anggaran Biaya (RAB) in units (IDR/USD). The cost budget plan (RAB) needs to adjust the price constant with the time and place of the disaster. The old and new buildings are considered the same price standard. This price is not constant, and the affected infrastructure is multiplied based on each criterion with the estimated cost budget coefficient, as seen in Table 2. We convert the money unit from rupiah (IDR) to dollar (USD).

In this research, we use a data unit house, building, and infrastructure map which take from regional planning map (RTRW) Bappeda. This data belonging information about the type of zone and building functions, and we surveyed classification sub-sector of house types I, II, and III.

Table 2. Coefficient Budget plan/ Rencana Anggaran Biaya (RAB)

\begin{tabular}{llllr}
\hline No & Sector & Sub Sector & Unit & $\begin{array}{l}\text { Price } \\
\text { Meter* }\end{array}$ \\
\hline I & Building and & House I / poor quality & $\mathrm{M}^{2}$ & \\
& Housing & House II / semi-permanent & $\mathrm{M}^{2}$ & 500.000 \\
& & House III / permanent & $\mathrm{M}^{2}$ & 1.000 .000 \\
& & House Trade and Service & $\mathrm{M}^{2}$ & 1.500 .000 \\
& & Building & $\mathrm{M}^{2}$ & 1.500 .000 \\
& & & 2.500 .000 \\
\hline
\end{tabular}




\begin{tabular}{llllr}
\hline II Social & Public health center & $\mathrm{M}^{2}$ & & 1.500 .000 \\
& School & $\mathrm{M}^{2}$ & & 1.500 .000 \\
& Worship place & $\mathrm{M}^{2}$ & & 800.000 \\
\hline III $\quad$ Infrastructure & Dirt road/ lansir & & $\mathrm{M}^{3}$ & 60.000 \\
& & & $\mathrm{M}^{3}$ & 450.000 \\
& Dirt road/onderlaag & & $\mathrm{M}^{3}$ & 100.000 \\
& Dirt road/Lapen & & $\mathrm{M}^{3}$ & 550.000 \\
& Environmental road/Hot & & \\
& mix & & \\
& Concrete Bridge & & $\mathrm{M}^{3}$ & 4.000 .000 \\
& wooden bridge & $\mathrm{M}^{3}$ & 2.500 .000 \\
& Office Park & $\mathrm{M}^{2}$ & $\mathrm{M}^{3}$ & 1.000 .000 \\
& Drainage & & $\mathrm{M}^{3}$ & 1.000 .000 \\
& Pier & & $\mathrm{M}^{3}$ & 1.500 .000 \\
\hline
\end{tabular}

Sources: Sesunan (2014).

* Note. Rate of exchange in 2014 is 12135 IDR = 1 USD. in this research we must to transform the billing to rate of exchange in 2020 is 14403 IDR $=1$ USD.

\section{Community Adaptation}

To direct observation and survey to become efficient, the researcher must follow the baseline map, which is the baseline map is the output scenario coastal flood. Using a baseline map, the researcher has not to cover outsides areas, useless data, and overload information. The field observations and surveys were carried out to reveal the factual conditions. We did the survey in OctoberNovember 2020, including before, after, and during flood phenomena. Nevertheless, in this observation activity and documentation, the observations were made about the efforts that the community has made to mitigate and adapt to coastal flooding disasters is primarily the way of adaptation in building construction in scenario coastal flood 2 meters.

\section{RESULT AND DISCUSSION}

Applying the flood inundation model using the principle of cost distance and Hllost as the coefficient of a land surface roughness represented an ideal inundation. In this study, we use a scenario of the maximum height of coastal flood at 2 meters as $\mathrm{H} 0$. The inundation model spread the floods over coastal areas with relatively flat and basins. Overall, several villages that are quite wide inundated by floods at the location of this study, namely the Kampong Baru, Tanjungpinang Timur, Tanjung Ayun Sakti, and Kelurahan Sei Jang village. The land cover type in the flood area has varied, ranging from houses, buildings, road networks / built-up areas, mangrove forests, tidal flat swamps.

Table 3. Impact of coastal flood

\begin{tabular}{|c|c|c|c|c|c|c|c|}
\hline \multirow[t]{2}{*}{ Sub District } & \multicolumn{6}{|c|}{ Building } & \multirow[b]{2}{*}{ Total } \\
\hline & $\begin{array}{l}\text { House/ } \\
\text { residence }\end{array}$ & $\begin{array}{l}\text { House Trade } \\
\text { and Services }\end{array}$ & Industry & Government & School & worship & \\
\hline Kampung Baru & 1087 & 147 & 9 & 2 & 0 & 0 & 1245 \\
\hline Tanjung Ayun Sakti & 1511 & 6 & 0 & 4 & 26 & 6 & 1553 \\
\hline $\begin{array}{l}\text { Tanjungpinang } \\
\text { Timur }\end{array}$ & 504 & 62 & 0 & 0 & 1 & 0 & 567 \\
\hline Sei Jang & 543 & 62 & 15 & 0 & 0 & 1 & 621 \\
\hline Melayu Kota Piring & 126 & & 0 & 0 & 0 & 0 & 126 \\
\hline Total & 3771 & 277 & 24 & 6 & 27 & 7 & 4112 \\
\hline
\end{tabular}



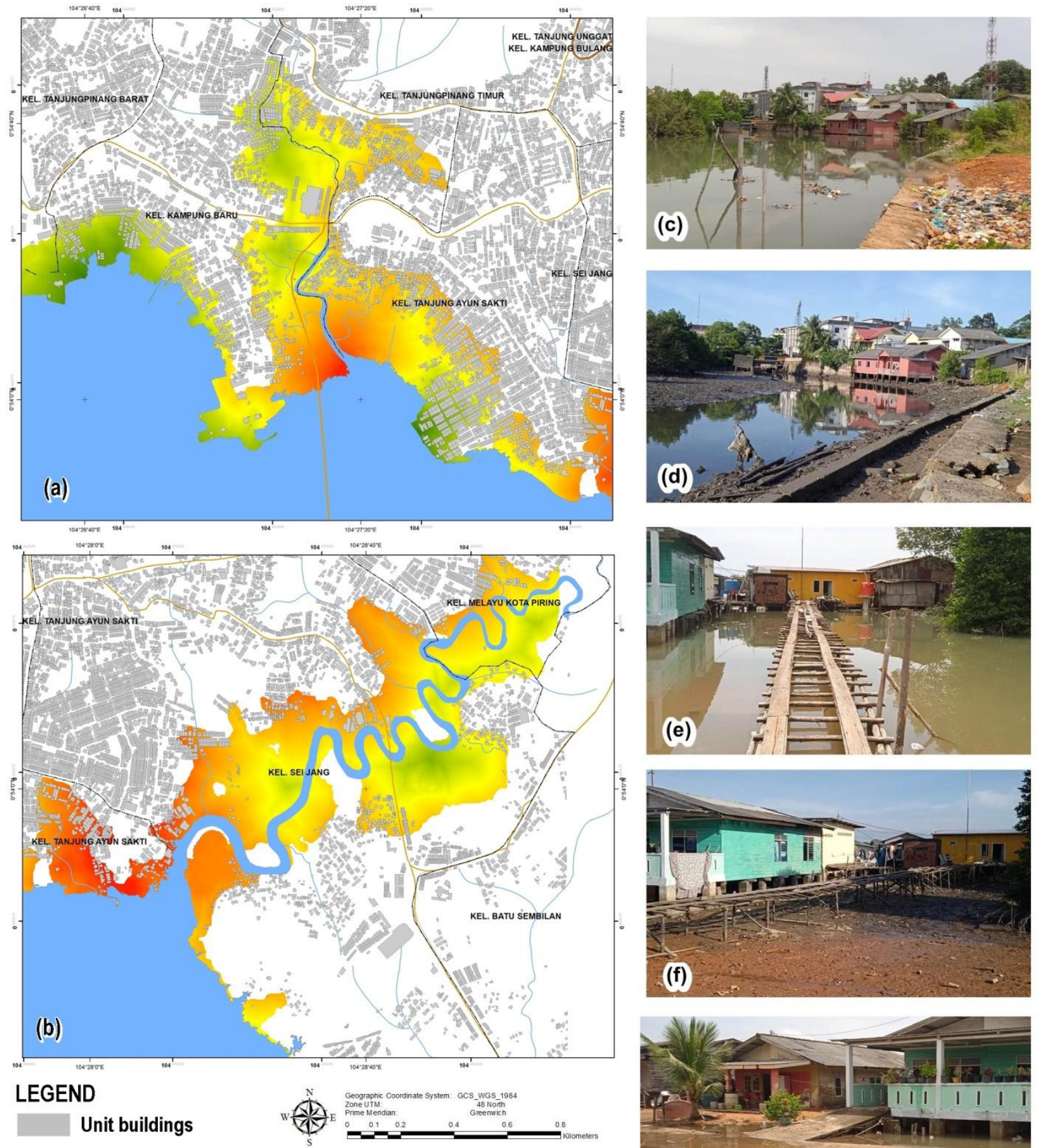

Flood Inundation
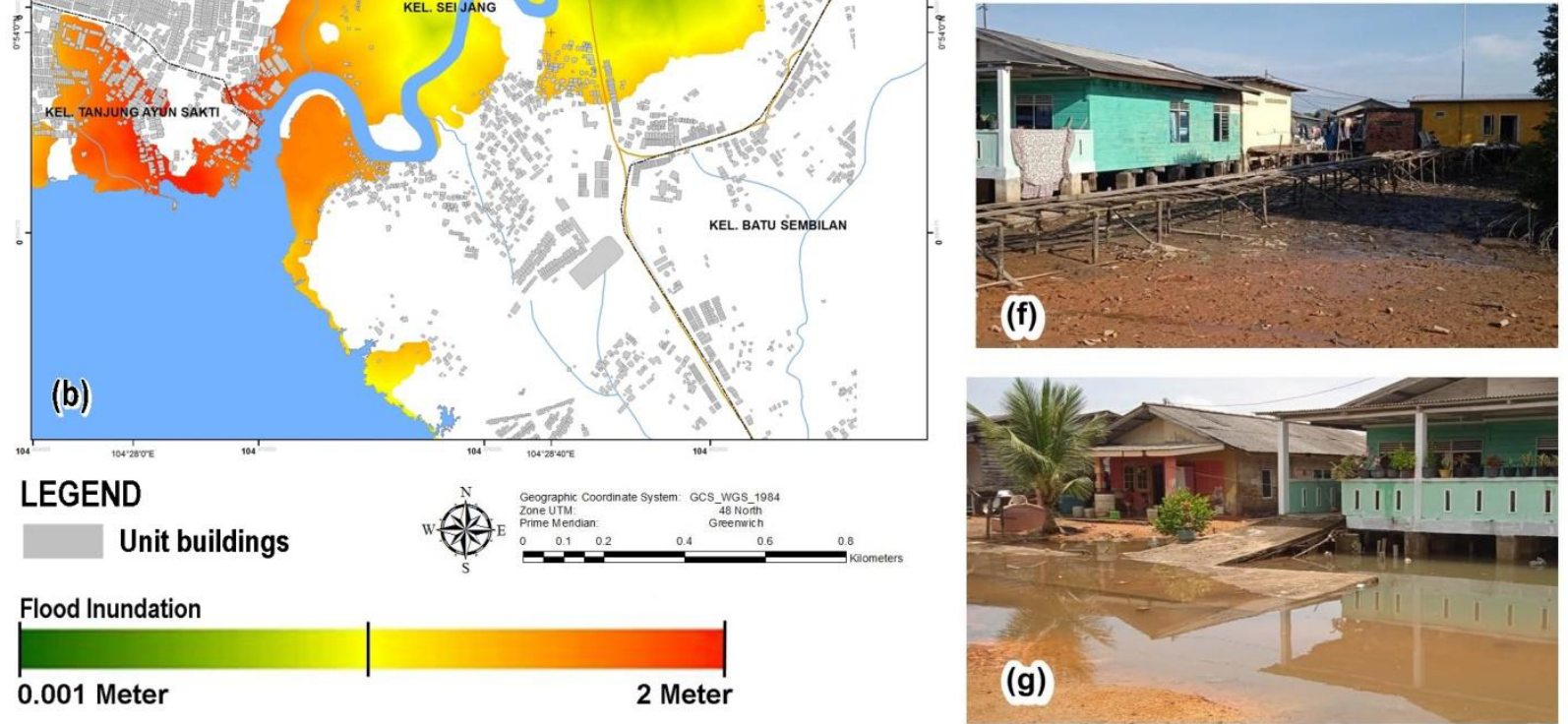

Figure 2. $\mathbf{A}$ and $\mathbf{b}$ is a map of a coastal flood. The red color indicates that the flood inundation is deeper, while the green color indicates shallow inundation. $\mathrm{C}$ is documentation of the existing area during level coastal flood at a number of 1 meter. $\mathbf{D}$ is the exact location when the flood dropped. $\mathbf{E}$ is the location of residential areas on the floodplain when a coastal flood occurs, $\mathbf{f}$ is a picture when coastal flood drops, and $\mathbf{g}$ is floods that inundate infrastructure. Source: Analysis data 2020.

Figure 2 is a coastal flood map which is describing the flood inundation and documentation. The dominant areas inundated by floods are locations around the rivers. This condition is also influenced by geomorphologies such as slope, altitude, floodplains, and back swamp. The flood inundation is also spread over tidal swamps and depression areas. River flow is indeed 
great transmission for inundation movements from the sea to the land. Generally, the flood variation is distributed around tidal floodplains, which reveals from the results of the geospatial model. The Hloss factor strongly influences it as an index of surface roughness, which reduces the strength of water movement.

Several spot locations on the shoreline are in the green zone, which is also strongly influenced by slope conditions and Hloss that affected the flood inundation is not high. This factor becomes the main point of attention in this study. The number of houses, buildings, and social facilities has been affected by coastal floods from this model. The houses affected by the coastal flood were founded in all of the areas. The building is spread over the coastal area, and this building has a considerable risk if this flood scenario. It will cause a significant loss because coastal flood occurs not influenced by the climate seasons, rainy days, it occurs at a precise time. If these disasters happened without a mitigation scenario and an adaptation strategy, they would become a mass loss.

Table 3 reveal about the number building covered by flood inundation in 5 sub-districts around the shoreline. Overall, residential houses are the most affected by tidal floods because this coastal area is dominated by houses for community settlements in total impacted at 3771 units. The distribution of the number of houses affected by this tidal flood follows the flood plain zone, not limited by administrative boundaries. The number of affected was calculated by calculating the number of houses affected and grouping them based on the function of building use. The most affected houses were Tanjung Ayun Sakti with 1511 units, the second with Kampung Baru of 1087 units, and Tanjungpinang Timur with 504 houses.

Meanwhile, buildings function as trade and services, which is supporting the community's economy, the most affected in Kampung Baru with a total number of 147, Sei Jang and Tanjungpinang Timur with a total of 62 . Furthermore, the economic supporting buildings are industrial buildings affected with 16 buildings in Sei Jang and Kampung Baru. There are 27 schools building, and 7 worships will take the impact of the flood. The calculation of the above data in more detail regarding the location and distribution of the number of houses affected by tidal flooding can be seen in Figure 2. It should be noted that the number of school building units was calculated in the group of social facilities such as schools, not the number of schools affected. We found that a school can have five or more building units.

Table 4 reveals the calculation of financial loss of restoration built environment in area flood inundation. It estimated the budget loss for buildings, settlements, and infrastructure due to the coastal flood by a maximum scenario of the coastal flood. Overall, the cost calculations referring to the $\mathrm{RAB}$, the development budget plan has succeeded in assessing the loss budget for the cost of recovering the physical condition of the environment. For building and housing, costs must be incurred to restore it with a value of 56519567.78 USD. Buildings and social facilities will require a restoration fee of 890936.46 USD. To recovery of infrastructure due to inundation is 4583510.51 USD. The total cost for the physical restoration of the environment is 61994014.75 USD. The calculation value was adjusted based on the Rupiah inflation value compared to the dollar value in 2014 and 2021. Referring to this report, we can anticipate and estimate unexpected budget allocations for disaster management efforts. This cost can be compared with the cost of managing the tidal flood environment, such as embankments to minimize the costs that must be incurred and determine the priority of disaster management strategies with the physical development of disaster management infrastructure. 
Table 4. The budget loss from the maximum flood inundation scenario

\begin{tabular}{|c|c|c|c|c|c|c|}
\hline \multirow[t]{2}{*}{ No } & \multirow[t]{2}{*}{ Sector } & \multirow[t]{2}{*}{ Sub Sector } & \multicolumn{2}{|c|}{$\begin{array}{c}\text { Impact flood } \\
\text { inundation scenario } \\
*\end{array}$} & \multicolumn{2}{|c|}{ Price } \\
\hline & & & Unit & Large Unit & IDR & USD* \\
\hline \multirow[t]{5}{*}{ I } & $\begin{array}{l}\text { Building } \\
\text { and }\end{array}$ & $\begin{array}{l}\text { House I / non- } \\
\text { permanent }\end{array}$ & 23 & $1126.14 \mathrm{M}^{2}$ & 668306321.38 & 46400.49 \\
\hline & Housing & $\begin{array}{l}\text { House II / semi- } \\
\text { permanent }\end{array}$ & 146 & $14391.8 \mathrm{M}^{2}$ & 17081590061.80 & 1185974.45 \\
\hline & & House III / permanent & 3602 & $401136.1 \mathrm{M}^{2}$ & 714161093733 & 49584190.36 \\
\hline & & $\begin{array}{l}\text { House Trade and } \\
\text { Service }\end{array}$ & 277 & $38541.7 \mathrm{M}^{2}$ & 68617565525.34 & 4764116.19 \\
\hline & & Industry and Industry & 24 & $7595.59 \mathrm{M}^{2}$ & 13522779081.58 & 938886.28 \\
\hline \multicolumn{2}{|c|}{ Total } & & 4072 & $462791.33 \mathrm{M}^{2}$ & 814051334723.12 & 56519567.78 \\
\hline \multirow[t]{3}{*}{ II } & Social & School & 27 & $5036.84 \mathrm{M}^{2}$ & 8967318482.08 & 622600.74 \\
\hline & & Worship & 7 & $2685.78 \mathrm{M}^{2}$ & 2550196248.21 & 177060.07 \\
\hline & & Government office & 6 & $738.42 \mathrm{M}^{2}$ & 1314643171.82 & 91275.65 \\
\hline \multicolumn{2}{|c|}{ Total } & & 19 & $8461.04 \mathrm{M}^{2}$ & 12832157902.10 & 890936.46 \\
\hline \multirow[t]{2}{*}{ III } & Infrastructu & Dirt road/ Lapen & & $709 \mathrm{M}^{3}$ & 84151025.96 & 5842.60 \\
\hline & re & $\begin{array}{l}\text { Environmental road/ } \\
\text { Hot mix }\end{array}$ & & $101000 \mathrm{M}^{3}$ & 65932150803.46 & 4577667.90 \\
\hline Tota & & & & $101709 \mathrm{M}^{3}$ & 66016301829.42 & 4583510.51 \\
\hline
\end{tabular}

* The maximum of flood inundation is 2 meters from shoreline

Sources: own analysis 2020

** Rate of money exchange in 2020 is 14403 IDR $=1$ USD, and the price difference in the last 6 years is 2268 IDR per 1 dollar.

Results of field observations carried out before and after coastal flooding were shown in Figure 2. The following is a photo of the documentation, where this image shows environmental conditions when the water level is low and when the tide is high. In picture a, we can see the mud outcrop in the tidal area. In the second picture, the flood inundation has

exceeded the limit of the seawater control embankment and has overflowed the land waste. We conducted further observations to prove that this coastal flood did indeed inundate part of the residential infrastructure. The following is an image of what was found in the field in several locations. When a coastal flood occurred, it flooded the streets and yards of residents.
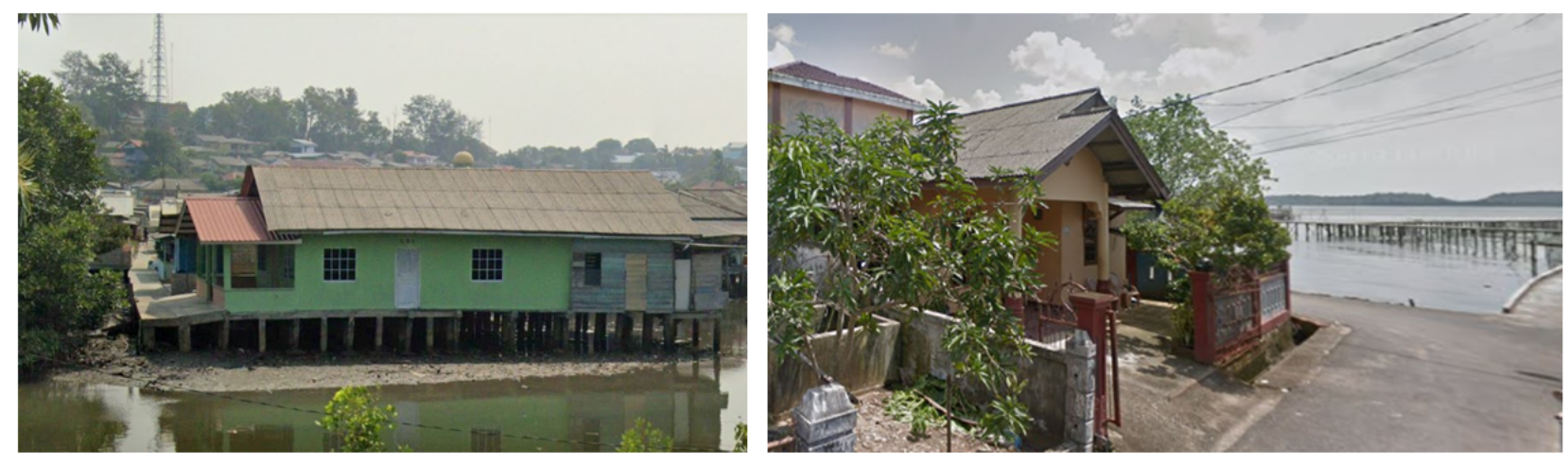

Figure 3. The effort community adaptation based on building constructions.

The field observation showed that the effort of the community adapts to geographical problems based on building constructions. We 109 found that several mitigation measures have been carried out, such as constructing flood retaining embankments. Functionally, the tidal 
flood embankment effectively reduces seawater runoff to land and reduces the volume of standing water. However, the embankments have been damaged to provide water gaps to propagate the low land surface around the tides. In several locations, we found that the community had adapted to housing infrastructure development. In the floodplain area, the building was built using the stilts concept to avoid being flooded. A simple bridge connects this housing to facilitate access in and out of the community. According to community capacity, the stilt houses built by the community, in general, have used concrete foundations only for the walls of the house.

We are glad to notify that some community infrastructure has adapted to the geomorphological conditions of the area, which often experiences coastal flood disasters. We can see a house on stilts with a concrete foundation connected by an overpass made of concrete and wood. Refer to the map of the modelling results of tidal inundation. We made observations on the green locations on the map, especially in the coastline area. We found the location relatively high from the tidal area. Mitigation efforts are carried out by piling up relatively high soil, then building the house's foundation on top of the piled soil. However, the houses will save from flood inundation at the number of 1 meter. When increasing seawater is more than 2 meters, these houses and buildings will be impacted by a coastal flood.

\section{CONCLUSION}

From the results of this study, we found that the stretch of coastal flood in this research location tends to be around the estuary and left and right of the river with relatively flat and low topography and has geomorphological characteristics of tidal swamps. Many settlements were affected by flooding from the spatial modeling scenario. Settlements affected by tidal flooding are on the coast, and infrastructure supports community accessibility. The estimated money spent on restoring the physical environment due to the flood disaster is sixty-one million USD. The government must be ready to provide a budget that will be used when an emergency occurs or undertake disaster management mitigation efforts by managing coastal areas to deal with tidal flooding. Several communities have tried to construct residential buildings for coastal floods in high wave 1 meter by constructing houses on stilts.

\section{REFERENCE}

Al'ala1 Musa, Syamsidik, and Kato Shigeru. 2017. Predicting Impact of SLR on Coastal Flooding in Banda Aceh Coastal Defences. Proceedings of the International Conference of Global Network for Innovative Technology and AWAM International Conference in Civil Engineering (IGNITE-AICCE'17) AIP Conf. Proc. 1892, 100004-1100004-8;

https://doi.org/10.1063/1.5005736.

Ackere V S. et al. 2016. 4D Coastal Flood Analysis and Visualization for Urban Area. Conference Paper.

Diez J.J. et al. 2013 Meteocean Influence on Inland and Coastal Floods in the East of Spain. Journal Coastal Research. DOI: 10.2112/JCOASTRES-D-11-00226.1

Holli Moh, 2012. Pemodelan Genangan Banjir Pasang Air Laur di Kabupaten Sampang Menggunakan Citra Satelit Alos dan Sistem Informasi Geografis. Proceeding. Seminar Nasional Kedaulatan Pangan, Fakultas Pertanian, Universitas Trunojoyo Madura.

Purnama, et al. 2015. Pemodelan Spasial Banjir Rob Berdasarkan Skenario Kenaikan Muka Air Laut Akibat Perubahan Ilim Global dan Analisis Dampaknya Terhadap Penggunaan Lahan di Kawasan Pesisir. Proceeding. Seminar Nasional Pengelolaan Pesisir dan Daerah Aliran Sungai. No.1.Yogyakarta. 9. April.

Haigh, I.D., Nicholls, R.J., Penning-Roswell, E. and Sayers, P. 2020. Impacts of climate change on coastal flooding, relevant to the coastal and marine environment around the UK. MCCIP Science Review 2020, 546-565. doi: 10.14465/2020.arc23.cfl

Hanif M, B G Putra, K Nizam, H Rahman and A. Y. Nofrizal. 2019. "Multi Spectral Satellite Data to Investigate Land Expansion and Related Micro Climate 
Change as Threats to the Environment", J. IOP Confer. Series: Earth Environ. Sci., Volume 303, 012030, Available at: $\quad$ https://doi.org/10.1088/17551315/303/1/012030.

Hanif M, Nofrizal Y A and Suasti Y. 2017. "Investigation Natural Forest Ecosystem Use High Resolution and Lidar Data", J. Environ. And Earth Sci., IIESTE, Volume 9, Issue 10, ISSN: 2225-0948.

Hidayat R A and Hanif M. 2020. Spatial Modelling of The Threat of Damage to The Peatland Ecosystem in The Mainland of Bengkalis Regency, Riau Province. Journal Social Polites. Vol 20. Special Issue. No 2. doi: 10.33541/sp.v21i3.2249

Indarto and Faisol Arif. 2013. Konsep Dasar Analisis Spasial. Andi Publisher. Jakarta. ISBN: 978-979-29-3354-3.

Irwan Sudra. 2016. Pemetaan Pasang Surut Dan Arus Laut Pulau Batam dan Pengaruhnya Terhadap Jalur Transportasi Antarpulau. Jurnal Kelautan. Volume 9, No. 1, April 2016. ISSN: 1907-9931 (print), 2476-9991.

Kopp, R.E., C.C. Hay, C.M. Little, and J.X. Mitrovica. 2015. Geographic variability of sea-level change. Current Climate Change Reports 1(3):192-204. Available:

https://doi.org/10.1007/s40641-0150015-5.

Lorie M. et.al. 2020. Modelling Coastal Flood Risk and Adaptation Response under Future Climate Conditions. Journal Climate Risk Management. https://doi.org/10.1016/j.crm.2020.100 233.

Nofrizal A Y. 2019. Prediction of Sea Water Flooding Hazard on Settlement Area in Padang City as Climate Changes Impact Using GIS and Remote Sensing. IOP Conf. Series: Earth and Environmental Science. 303. Doi:10.1088/17551315/303/1/012025.

Priana Ayi, Marfai Aris Muh. 2019. Coastal Flood Assessment by Mean of GIS Technology. Faculty of Geography, Universitas Gadjah Mada, Indonesia.

Rahman H, Triyatno, Hanif M, Indrayani P.
2020. Spatial Assessment of Landscape Structure Changes and Ecological Connectivity in Padang Pariaman. Journal of Remote Sensing GIS and Technology, 6(2).

Sutirto and Diarto. 2014. Gelombang dan arus laut lepas. Kupang: Graha Ilmu.

Sesunan Dirwansyah. 2014. Analisis Kerugian Akibat Banjir di Bandar Lampung. Jurnal Teknik Sipil UBL Volume 5 No. 1 April 2014.

Sayers, P.B., Hall, J.W. and Meadowcroft, I.C. (2002) Towards risk-based flood hazard management in the UK. Civil Engineering, 150(5), 36-42.

Tiggeloven T, et.al. 2020. Global-scale benefit-cost analysis of coastal flood adaptation to different flood risk drivers using structural measures. Journal Nat. Hazards Earth Syst. Sci., 20, 10251044, 2020. https://doi.org/10.5194/nhess-20-10252020

Zahro Qoriatu. 2017. Kajian Spasial Risiko Bencana Tsunami Kabupaten Serang, Banten. Jurnal Sains dan Teknologi Mitigasi Bencana, Vol. 12, No. 1, Juni.

Zevenbergen Chris, et.al. 2011. Urban flood management. Taylor \& Francis Group, London, UK. ISBN: 978-0-415-559447.

Wdowinski, et.al. 2020. Land subsidence contribution to coastal flooding hazard in southeast Florida. Journal Proc. IAHS, 382, 207-211, 2020. https://doi.org/10.5194/piahs-382-2072020. 